\title{
Les lieux de mémoire w przestrzeni Lublina - między teorią a praktyką*
}

\section{Realms of memory in Lublin - between theory and practice}

Dublikacja wydana z okazji 700. rocznicy lokacji Lublina jest jednym blicznej i edukacyjnej w polskiej literaturze. Miejsca pamięci - jak przekonują w książce Dominika Staszczyk i Andrzej Stępnik - to „fenomeny historyczne, czyli topograficznie wyodrębnione miejsca, wybrane wydarzenia, artefakty, postaci, symbole i idee, które wpłynęły lub mają wpływać na kształtowanie się tożsamości danej wspólnoty" (s. 19), to miejsca szczególnie ważne dla danej wspólnoty. Redaktorzy publikacji za cel postawili sobie naukowe podejście do problemu niezbyt często poddawanego refleksji naukowej. Jak przekonuje autor wstępu Dariusz Słapek, omawiany tom

Lubelskie miejsca pamięci w przestrzeni publicznej i edukacyjnej, red. M. Ausz, J. Bugajska-Więcławska, D. Staszczyk, A. Stępnik, D. Szewczyk, Wydawnictwo Instytutu Historii Uniwersytetu Marii Curie-Skłodowskiej, Lublin 2015, ss. 327, ISBN: 9788393608621. 
kreuje [...] ważny (w dyskursie głównie publicystycznym) porządek rzeczy, organizuje kwestie terminologii, konstruuje właściwe jej rozumienie, służy komparatystyką, a daleki od apodyktyczności podpowiada i sugeruje (w tym kontekście jawi się ponadlokalny wymiar książki) (s. 10).

Poddano więc analizie miejsca pamięci, miejsca symboliczne, metaforycznie topograficznie wartościowane w wymiarze lokalnym, jednak analizowane problemy i wysunięte propozycje badawcze mogą służyć jako przykład dla podobnych opracowań innych małych ojczyzn. Warto zwrócić szczególną uwagę zwłaszcza na niektóre z zamieszczonych w tomie tekstów.

Publikacja została podzielona na trzy części. Pierwsza, zatytułowana Próba rewitalizacji miejsc - między teoriq a praktyka, jest wstępem do prezentowanych badań, zwłaszcza otwierający ją artykuł o miejscach pamięci w przestrzeni publicznej i badaniach naukowych (s. 15-42). Jego autorzy - Dominika Staszczyk i Andrzej Stępnik - przedstawili genezę pojęcia „miejsce pamięci”, scharakteryzowali rozwój memorologii (pamięcioznawstwa) i zwrócili uwagę na jej połączenie z polityką historyczną państwa w przypadku Polski. Z powodu trudnej i bolesnej historii XX wieku, zwłaszcza II wojny światowej, w przestrzeni publicznej termin „miejsce pamięci” kojarzono przede wszystkim z miejscami bitew, martyrologia, cmentarzami i grobami. Autorzy tego artykułu zwrócili uwagę na pełnienie przez miejsca pamięci określonych funkcji: integracyjnej (jednoczącej daną wspólnotę wokół konkretnych wartości, idei, wzorców zachowań), socjalizującej (promującej dziedzictwo kulturowe) czy estetyzacyjnej. Tekst ten jest szczególnie ważny także dlatego, że stanowi swego rodzaju podsumowanie literatury na temat miejsc pamięci, pamięci zbiorowej, kulturowej. Zaprezentowano dokonania jej głównych badaczy z różnych krajów (m.in. Pierre’a Nory, Mario Isnenghiego, Étienne’a François i Hagena Schultze'a, Emila Brixa, Ernsta Bruckmüllera i Hannesa Stekla, Andrzeja Szpocińskiego, Roberta Traby).

Druga część książki została zatytułowana Upamiętnianie $i$ celebracje. Podjęto w niej m.in. temat lubelskich pomników analizowanych 
$\mathrm{z}$ artystycznego i kulturowego punktu widzenia. Autor jednego z artykułów - Kazimierz S. Ożóg - zwrócił uwagę przede wszystkim na pomniki wybudowane po 1945 roku. Zajęto się więc problematyką aktualnej przestrzeni miasta. Ożóg postawił jednocześnie ciekawe pytanie: jakich budowli tego typu w mieście brakuje? - i przedstawił swoje propozycje (s. 108-110). W kolejnych tekstach dwaj pracownicy Państwowego Muzeum na Majdanku - Tomasz Kranz i Wiesław Wysok - przywołali to miejsce w przestrzeni Lublina oraz przedstawili dydaktyczny wymiar tej instytucji (s. 113-157). Oprócz historii Muzeum zaprezentowano jego działalność, zwłaszcza dotyczącą edukacji historycznej, prezentując różnorodne metody pracy dydaktycznej w tym miejscu pamięci. Z jednej strony są to tradycyjne już metody, jak chociażby korzystanie z biografii konkretnych postaci, z drugiej - nowsze, skupione na praktyce, jak na przykład workcamp (warsztaty historyczne z jednoczesnymi pracami porządkowymi na terenie Majdanka). Wysok przedstawił także opinie uczniów biorących udział w projektach edukacyjnych prowadzonych przez Muzeum.

Ostatnia część omawianej publikacji skupia się na praktycznym wykorzystaniu podjętej problematyki. Są to Propozycje dydaktyczne pracowników lubelskiego uniwersytetu, ale przede wszystkim nauczycieli lubelskich szkół. Warto podkreślić, że zostały przez nich wykorzystane także źródła literackie, które przez historyków są często niedoceniane lub są zaledwie uzupełnieniem źródeł stricte historycznych. W jednym z artykułów znajdujących się w tej części Małgorzata Latoch-Zielińska ponownie przedstawiła różnorodne definicje pojęcia „miejsce pamięci” (s. 195-197). Następnie zaprezentowała miejsca pamięci w twórczości Józefa Czechowicza. Co warte podkreślenia, przywołała nie tylko miejsca, które poeta opisywał, lecz także te, które fotografował. W tekście tym pojawili się również inni pisarze i ich teksty „oprowadzające” po Lublinie, jak chociażby Franciszka Arnsztajnowa, Julia Hartwig, noblista Isaac Bashevis Singer czy Marcin Wroński. Teksty literackie zaprowadziły autorkę do możliwości ich wykorzystania w praktyce - stworzenia gry literackiej czy projektu. Drugim ważnym, dopełniającym treściowo tekstem na ten temat jest artykuł Doroty Kapicy-Łyjak prezentujący Lublin przez pryzmat twórczości Arnsztajnowej i Czechowicza, których wiersze wspólnie opublikowano w 1933 i 1934 roku. Na tej podstawie nauczycielka stworzyła szlaki literackie po Lublinie, których po- 
szczególne przystanki ukazują miasto w różnych kontekstach: chronologicznym, przestrzennym, społecznym. $Z$ kolei Anna Ausz zajęła się poezją Jana Kochanowskiego. Wykorzystała ją do scenariusza lekcji dla klas gimnazjalnych i ponadgimnazjalnych.

W tej części publikacji podjęto także temat wycieczek po mieście i odgrywanej przez nie roli w edukacji historycznej. W innym artykule wykorzystano relacje świadków II wojny światowej, które zestawiono z twórczością Krzysztofa Kamila Baczyńskiego. Następne dwa artykuły to scenariusze: zajęć dotyczących września 1939 roku w Lublinie oraz gry miejskiej na temat pomników i miejsc pamięci.

Wydaje się, że autorom udało się zrealizować często wysuwany, ale nierealizowany postulat interdyscyplinarności. Zebrane teksty mogą być wykorzystane przez historyków, polonistów, etnologów, socjologów. Przede wszystkim jednak przez dydaktyków - nie tylko historii, co potwierdza szerokie spojrzenie na badaną problematykę. Książka została bardzo dobrze opracowana merytorycznie. Kolejne teksty stopniowo przechodzą od ujęć teoretycznych, przez teoretyczno-praktyczne, do praktycznych, w dużej mierze będących gotowymi pomocami dla nauczycieli. Ponadto zamieszczono dużą liczbę ilustracji prezentujących lubelskie miejsca pamięci. Bez nich publikacja straciłaby na użyteczności dla mieszkańców spoza Lublina. Należy docenić przede wszystkim walory praktyczne tej pozycji. Z pewnością tom można polecić nauczycielom, edukatorom, muzealnikom i innym mentorom, zwłaszcza przedstawicielom młodego pokolenia.

Joanna Orzet 